\title{
KEANGGOTAAN KELOMPOK TANI DAN KAITANNYA DENGAN AKSES TERHADAP SUMBER PEMBIAYAAN USAHA TANI PISANG DI KABUPATEN CIANJUR
}

\author{
Irfan Handriyadi ${ }^{1}$ dan Eliana Wulandari ${ }^{2}$ \\ ${ }^{1}$ Dinas Pertanian Perkebunan Pangan dan Hortikultura Kabupaten Cianjur \\ ${ }^{2}$ Fakultas Pertanian, Universitas Padjadjaran \\ Email: handriyadi.irfan@gmail.com
}

\begin{abstract}
ABSTRAK
Kelompok tani berperan penting bagi petani yang bergabung di dalamnya karena dapat berbagi informasi mengenai manajemen usaha tani dan akses terhadap berbagai jenis pembiayaan. Petani pada umumnya dapat mengakses pembiayaan dari berbagai sumber pembiayaan seperti dari bank, lembaga keuangan mikro, pemerintah, pedagang, kios input pertanian, dan pinjaman dari keluarga, tetangga dan teman. Tujuan dari penelitian ini adalah untuk menganalisis bagaimana akses pembiayaan petani yang bergabung dalam keanggotaan pada kelompok tani. Metode survei dilakukan dalam pengumpulan data dari enam puluh petani pisang di sentra produksi pisang di Kabupaten Cianjur. Data dianalisis dengan menggunakan independent $t$-test untuk melihat perbedaan akses pembiayaan antara petani yang merupakan anggota kelompok tani dan petani yang bukan anggota pada kelompok tani. Hasil analisis menunjukkan bahwa petani yang menjadi anggota kelompok tani memiliki akses yang lebih baik terhadap kredit dari bank dan lembaga keuangan mikro, dan pembiayaan in-kind dari pemerintah dan pedagang. Temuan penelitian ini menunjukkan pentingnya memotivasi petani untuk bergabung pada kelompok tani untuk mendapatkan kesempatan lebih besar dalam mengakses pembiayaan dari berbagai sumber pembiayaan.
\end{abstract}

Kata kunci: akses pembiayaan, kelompok tani, pisang

\begin{abstract}
Farmers' group plays important role for farmers who join with the farmers' group in sharing the information of farming management and access to many sources of finance. In general, farmers can access finance from many financial sources such as from bank, micro finance institution, government, trader/buyer, agricultural input kiosk, and from other financial sources such as from family, neighbors or friends. This research aims to analyze financial access of farmers who join with farmers' group. Survey was conducted to collect data from sixty banana farmers in the centre of banana production in Cianjur District. The data was analyzed using independent $t$-test to see the difference of financial access between two groups of farmers, i.e. farmers who are member of farmers' group and farmers who are not. The results of this research show that farmers who are member of farmers' group have better access to commercial credit from bank and micro finance institution, and in-kind finance from government and trader/buyer. The findings of this research show the importance to motivate farmers to join with a farmers' group to have a better opportunity in accessing finance from different financial sources.
\end{abstract}

Keywords: financial access, farmers group, banana 


\section{PENDAHULUAN}

Pertanian merupakan salah satu sektor penggerak perekonomian di Indonesia, dimana profesi sebagai petani masih merupakan pelaku utama dalam usaha pertanian di Indonesia. Berdasarkan sensus pertanian tahun 2013, jumlah rumah tangga petani di Indonesia mencapai 26.135.469 rumah tangga (Statistik Indonesia, 2013). Meskipun jumlah petani sangat besar namun pendapatan yang mereka hasilkan dari sektor pertanian masih belum optimal. Salah satu masalah klasik yang petani hadapi adalah kurang tersedianya pembiayaan untuk mendukung kelangsungan usaha pertanian mereka.

Masalah pembiayaan dalam usaha pertanian tidak hanya dihadapi oleh petani tanaman pangan seperti padi, jagung dan kedelai. Akan tetapi, petani hortikultura juga menghadapi masalah yang terkait dengan pembiayaan usaha tani (Subagio, 2008), salah satunya adalah petani pisang. Petani pisang di beberapa sentra produksi mengalami permasalahan pembiayaan yang sama. Produk pertanian merupakan usaha yang memiliki risiko dalam hal fluktuasi kuantitas dan kualitas produksi. Hal ini mengakibatkan kurangnya minat berbagai lembaga pembiayaan untuk membiayai usaha pertanian, termasuk usaha tani pisang. Selain itu, karakteristik tanaman pisang yang hanya memiliki satu periode produksi membuat petani mengalami kesulitan dalam hal pembayaran pinjaman secara bulanan. Kondisi ini membuat petani takut untuk mengajukan pinjaman modal dari lembaga keuangan formal.

Terdapat beberapa sumber pembiayaan yang dapat diakses oleh petani seperti dari bank, koperasi dan kerabat (Armendariz dan Labie 2011), serta dari lembaga keuangan mikro (LKM) (Bastin dan Matteucci 2007). Permodalan juga bisa diperoleh dari programprogram pemerintah yang umumnya dalam bentuk barang sarana produksi pertanian (pembiayaan in-kind) yang disalurkan melalui kelompok tani (Wulandari dkk. 2017). Tidak seperti bank komersial yang membutuhkan jaminan, permodalan yang berasal dari pemerintah dan beberapa pembeli besar mensyaratkan petani yang hendak mengakses permodalan harus bergabung pada suatu asosiasi petani atau kelompok tani.

Kelompok tani memainkan peran penting dalam pengembangan pertanian (Wahyuni 2003). Bergabung dengan kelompok tani dapat memberikan keuntungan bagi petani anggotanya. Melalui kelompok tani, petani dapat meningkatkan pengetahuan, sikap dan keterampilan mereka dalam bertani (Novia 2011). Sebagai anggota asosiasi petani, petani dapat berbagi pengalaman dan informasi di sektor pertanian (Moobi dan Oladele 2012). Selanjutnya, petani yang tergabung dalam asosiasi petani memiliki hubungan positif dengan efisiensi teknis pertanian (Waryanto dkk. 2014).

Penelitian ini bertujuan untuk menganalisis akses pembiayaan petani terkait dengan keanggotaan pada kelompok tani. Hasil penelitian ini memberikan wawasan kepada pemerintah tentang peran kelompok tani dalam meningkatkan kesempatan untuk mengakses pembiayaan dari berbagai sumber pembiayaan.

\section{METODE PENELITIAN}

Metode yang digunakan dalam penelitian ini adalah survei. Penelitian ini melibatkan enam puluh petani pisang di sentra produksi pisang di Kabupaten Cianjur, yaitu Kecamatan Sukaresmi dan Cibeber. Penelitian ini berfokus pada komoditas pisang karena komoditas pisang merupakan salah satu komoditas penting untuk pengembangan hortikultura di Indonesia (Kementerian Pertanian RI 2011).

Data yang digunakan dalam penelitian ini adalah pengalaman petani dalam mendapatkan pembiayaan dari berbagai sumber pembiayaan yaitu kredit dari bank dan lembaga keuangan mikro (LKM), pembiayaan dalam bentuk barang (in-kind) dari pemerintah yang disalurkan melalui kelompok tani, pembiayaan dari pedagang, pembayaran input yang fleksibel dari kios input pertanian dan pembiayaan dari sumber pembiayaan lainnya seperti dari keluarga, tetangga dan teman. Pada penelitian ini, petani dikategorikan menjadi dua grup petani, yaitu petani yang bergabung sebagai anggota kelompok tani dan petani yang tidak bergabung sebagai anggota kelompok tani. Data dianalisis dengan menggunakan independent $t$-test untuk menganalisis perbedaan akses terhadap pembiayaan antara petani yang merupakan anggota kelompok petani dan petani yang tidak menjadi anggota dari suatu kelompok tani. Uji normalitas dilakukan sebelum independent $t$ test, yaitu dengan menggunakan uji Kolmogorov Smirnov. 


\section{HASIL DAN PEMBAHASAN}

Gambar 1 menyajikan aksesibilitas petani terhadap berbagai sumber pembiayaan yang berbeda. Gambar 1 menunjukkan bahwa mayoritas petani mempunyai pengalaman dalam mendapatkan pembiayaan dari pemerintah (27 persen) dan dari keluarga, tetangga dan teman (25 persen). Gambar 1 juga menunjukkan bahwa pembiayaan usaha tani yang diberikan oleh lembaga formal seperti bank dan LKM kurang dapat diakses oleh banyak petani karena hanya sekitar 17 dan 4 persen petani yang dapat memperoleh pembiayaan dari lembaga pembiayaan formal tersebut. Penelitian terdahulu menyebutkan bahwa petani di Indonesia menghadapi kesulitan dalam mendapatkan pembiayaan yang bersumber dari dari lembaga formal (Hartono dkk. 2013). Sumber pembiayaan informal telah menjadi sumber pembiayaan utama bagi sebagian besar rumah tangga petani (Pham dan Lensink 2007).

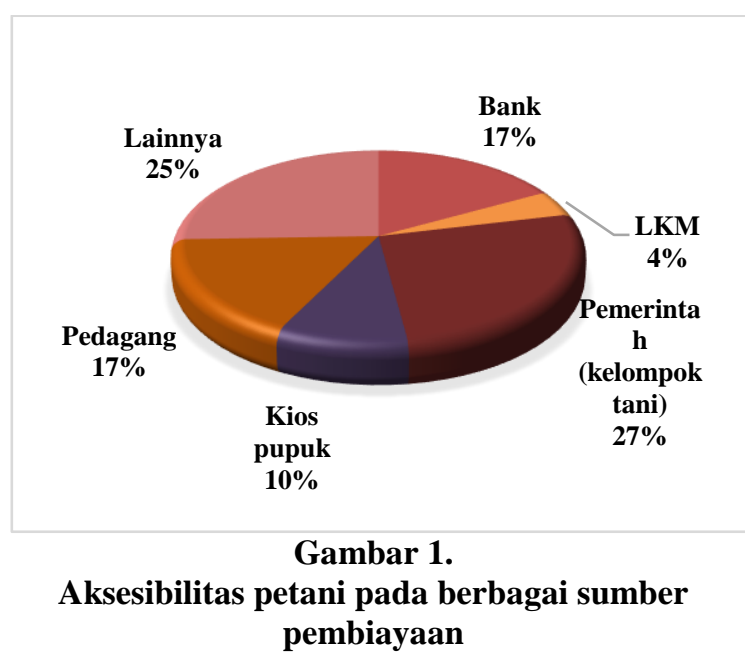

Persentase petani yang dapat mengakses pembiayaan dari berbagai sumber pembiayaan berdasarkan keanggotaan kelompok tani disajikan pada Tabel 1. Tabel 1 menunjukkan bahwa sebagian besar petani yang menjadi anggota kelompok tani mempunyai pengalaman dalam mendapatkan pembiayaan yang berasal dari pemerintah yang disalurkan melalui kelompok tani (64 persen). Sebagian besar petani yang tidak tergabung dalam suatu kelompok tani mempunyai pengalaman dalam mendapatkan pembiayaan dari keluarga, teman ataupun tetangga (43 persen). Keanggotaan pada suatu asosiasi petani memiliki pengaruh signifikan terhadap partisipasi pada pasar keuangan informal (Moobi dan Oladele 2012).
Tabel 1.

Persentase petani yang mendapatkan pembiayaan dari sumber pembiayaan yang berbeda berdasarkan keanggotaan pada suatu kelompok tani

\begin{tabular}{lllll}
\hline \multirow{2}{*}{$\begin{array}{l}\text { Sumber } \\
\text { Pembiayaan }\end{array}$} & \multicolumn{2}{l}{$\begin{array}{l}\text { Tidak mendapat } \\
\text { pembiayaan }\end{array}$} & \multicolumn{2}{l}{$\begin{array}{l}\text { Mendapat } \\
\text { pembiayaan }\end{array}$} \\
\cline { 2 - 5 } & Anggota $\begin{array}{l}\text { Bukan- } \\
\text { anggota }\end{array}$ & Anggota & $\begin{array}{l}\text { Bukan- } \\
\text { anggota }\end{array}$ \\
\hline Bank & 0,64 & 0,90 & 0,36 & 0,10 \\
LKM & 0,90 & 1,00 & 0,10 & 0,00 \\
Pemerintah & 0,36 & 1,00 & 0,64 & 0,00 \\
(Kelompok & & & & \\
Tani) & & & & \\
Pedagang & 0,64 & 0,90 & 0,36 & 0,10 \\
Kios pupuk & 0,85 & 0,86 & 0,15 & 0,14 \\
Sumber lainnya & 0,62 & 0,57 & 0,38 & 0,43 \\
\hline
\end{tabular}

Nilai rata-rata variabel untuk uji independent $t$-test bagi petani yang merupakan anggota maupun yang bukan merupakan anggota kelompok tani terhadap akses pembiayaan dari berbagai sumber pembiayaan disajikan pada Tabel 2. Hasil uji independent $t$ test menunjukkan bahwa keanggotaan kelompok tani mempunyai perbedaan yang signifikan dalam mengakses pembiayaan dari berbagai sumber pembiayaan. Hasil menunjukkan bahwa petani yang bergabung dalam suatu kelompok tani memiliki perbedaan signifikan dalam memperoleh kredit dari bank dan lembaga keuangan mikro jika dibandingkan dengan petani yang bukan merupakan anggota suatu kelompok tani. Demikian pula, terdapat perbedaan yang signifikan antara petani yang menjadi anggota kelompok tani dengan yang bukan anggota kelompok tani dalam memperoleh pembiayaan dari pemerintah dan pedagang. Hasil uji independent $t$-test tersebut menyiratkan bahwa dengan menjadi anggota kelompok tani, menjadikan petani memiliki kesempatan yang lebih baik dalam mendapatkan akses pada kredit dari bank dan lembaga keuangan mikro, serta mendapatkan pembiayaan in-kind dari pemerintah (kelompok tani) dan pedagang. Pembiayaan yang diberikan melalui kelompok petani memiliki peluang lebih tinggi untuk sukses (Supriatna 2009). Gemiharto dkk. (2016) menyebutkan bahwa petani yang bergabung dalam suatu kelompok tani dapat direkomendasikan untuk mendapatkan pembiayaan. Selain itu, akses pembiayaan yang lebih baik dapat meningkatkan produksi pertanian (Muchtar dkk. 2015). 
Tabel 2.

Nilai rata-rata variabel untuk puji independent t-test

\begin{tabular}{|c|c|c|c|}
\hline \multirow[b]{2}{*}{$\begin{array}{l}\text { Sumber } \\
\text { pembiayaan }\end{array}$} & \multicolumn{2}{|c|}{ Keanggotaan } & \multirow{2}{*}{$\begin{array}{l}\text { Signifikansi } \\
\text { perbedaan } \\
\text { pada taraf } 5 \\
\text { persen }\end{array}$} \\
\hline & $\begin{array}{l}\text { Bukan } \\
\text { anggota }\end{array}$ & Anggota & \\
\hline Bank & 0,10 & 0,36 & signifikan \\
\hline LKM & 0,00 & 0,10 & signifikan \\
\hline $\begin{array}{l}\text { Pemerintah } \\
\text { (Kelompok } \\
\text { Tani) }\end{array}$ & 0,00 & 0,64 & signifikan \\
\hline Pedagang & 0,10 & 0,36 & signifikan \\
\hline Kios pupuk & 0,14 & 0,15 & $\begin{array}{l}\text { tidak } \\
\text { signifikan }\end{array}$ \\
\hline Lainnya & 0,43 & 0,38 & $\begin{array}{l}\text { tidak } \\
\text { signifikan }\end{array}$ \\
\hline
\end{tabular}

\section{KESIMPULAN}

Hasil analisis independent t-test menunjukkan bahwa keanggotaan kelompok tani membantu petani dalam meningkatkan kesempatan akses pembiayaan dari berbagai sumber pembiayaan. Dengan menjadi anggota kelompok tani, petani memiliki akses yang lebih baik terhadap kredit dari bank dan lembaga keuangan mikro, pembiayaan in-kind dari pemerintah yang disalurkan melalui kelompok tani dan pembiayaan dari pedagang. Temuan penelitian ini menunjukkan pentingnya memotivasi petani untuk bergabung pada suatu kelompok tani untuk mendapatkan kesempatan lebih besar dalam mendapatkan pembiayaan dari berbagai sumber pembiayaan.

\section{DAFTAR PUSTAKA}

Armendariz, B., \& Labie, M. (2011). The Handbook of Microfinance. World Scientific Publishing Co. Pte. Ltd.

Bastin, A., \& Matteucci, N. (2007). Financing coffee farmers in Ethiopia: challenges and opportunities. Savings and Development, 31(3), 251-282.

Gemiharto, I., Zein, D., \& Karimah, K. E. (2016). Evaluasi model komunikasi pemasaran koperasi dalam upaya penguatan kelembagaan ekonomi masyarakat. Jurnal Manajemen Komunikasi, 1(1), 57-78.

Hartono, R., Hadi, S., Juanda, B., \& Rusastra, I. W. (2013). Penyusunan alternatif model kelembagaan kredit usaha pertanian di perdesaan. Informatika Pertanian, 22(2), 121-135.
Kementrian Pertanian RI. (2011). Pedoman teknis pelaksanaan pengembangan hortikultura tahun 2012. Direktorat Jenderal Hortikultura, Kementrian Pertanian RI. Jakarta, Indonesia.

Machethe, C. L. (2004). Landbouw en armoede in Zuid-Afrika: Can agriculture reduce poverty. In Paper presented at the Overcoming Underdevelopment Conference held in Pretoria, 28, 29.

Moobi, M. N., \& Oladele, O. I. (2012). Factors influencing small-scale farmers' participation in informal financial markets in Mafikeng Municipality. Journal of Food, Agriculture \& Environment, 10(2), 1133-1137.

Muchtar, K., Susanto, D., \& Purnaningsih, N. (2015). Adopsi teknologi petani pada sekolah lapangan pengelolaan tanaman terpadu (SL-PTT). Jurnal Penyuluhan, 11(2), 176-185.

Novia, R. A. (2011). Respon petani terhadap kegiatan sekolah lapangan pengelolaan tanaman terpadu (SLPTT) di Kecamatan Ajibarang Kabupaten Banyumas. Mediagro, 7(2), 48-60.

Pham, T., \& Lensink, R. (2007). Lending policies of informal, formal and semiformal lenders: evidence from Vietnam, Economics of Transition, 15(2), 181-209.

Subagio, H. (2008). Peran kapasitas petani dalam mewujudkan keberhasilan usahatani: kasus petani sayuran dan padi di Kabupaten Malang dan Pasuruan Provinsi Jawa Timur. Dissertation.

Supriatna, A. (2009). Pola pelayanan pembiayaan sistem kredit mikro usaha tani di tingkat pedesaan. Jurnal Litbang Pertanian, 28(3), 111-118.

Wahyuni, S. (2003). Kinerja kelompok tani dalam sistem usaha tani padi dan metode pemberdayaannya. Jurnal Litbang Pertanian, 22(1), 1-8.

Waryanto, B., Chozin M. A., Dadang, \& Putri, E. I. K. (2014). Environmental Efficiency Analysis of Shallot Farming: A Stochastic Frontier Translog Regression Approach. Journal of Biology, Agriculture and Healthcare, 4(19), 87-100.

Wulandari, E., Meuwissen, M., Karmana, M. H., \& Oude Lansink, A. (2017). Performance and access to finance in Indonesian horticulture. British Food Journal, 119(3), 625-638. 
Vol. 2, No. 2, Desember 2017: 291-357 AGRICORE-Jurnal Agribisnis dan Sosial Ekonomi Pertanian 